\title{
The Commercialisation of Modern Islamic Insurance Providers: A Study of Takaful Business Frameworks in Malaysia
}

\author{
Kamaruzaman Noordin ${ }^{1 *}$, \\ Mohd. Rizal Muwazir @Mukhazir ${ }^{1}$ \\ Azian Madun ${ }^{1}$ \\ ${ }^{1}$ Department of Shariah and Management Academy of Islamic Studies \\ University of Malaya, 50603 Kuala Lumpur, Malaysia \\ Tel: +603-79676013 \\ *Corresponding Author, Email: zamann@um.edu.my
}

\begin{abstract}
A commercial insurance contract is deemed invalid by many Muslim scholars due to the fact that it is a mu awada (financial exchange) contract, which is overwhelmed by prohibited elements such as gharar (uncertainty), riba (interest), and maysir (gambling). As an alternative, a Shariacompliant insurance scheme (also known as takaful) that supposedly run on the principles of mutual co-operation was proposed by the scholars and subsequently institutionalized in the late 1970s. Nevertheless, after more than 30 years, it appears that the majority of takaful operators currently exist worldwide were established as joint-stock or public limited companies (PLCs). As a result, it could be argued that the original concept of takaful was later overshadowed by the element of profit-making as observed in commercial insurance entities. This paper therefore sets out to examine those issues, which directly relate to this form of commercialisation. It argues that since the establishment of insurance companies based on commercial framework is impermissible, it could possibly affect the validity of present takaful arrangement. This study is mainly qualitative and relies greatly upon the documentation method. It is also based on a fieldwork method, since the business models adopted by several takaful operators in Malaysia are carefully examined. In general, it is found that the characteristics of a commercial takaful entity may not necessarily be similar to that of its conventional counterpart.
\end{abstract}

Keywords: Takaful, tabarru', mudarabah, ji alah, wakalah.

\section{A. INTRODUCTION}

The issue of the legal status of insurance contracts has been discussed and debated by Muslim jurists since as early as the $18^{\text {th }}$ century and has continued for more than a century, ('Ali Muhyi alDin al-Qarradaghi, 2005). To date, Muslim scholars from all over the world have issued hundreds of legal opinions regarding insurance contracts, either as individual opinions or group resolutions. Some regard the insurance contract to be invalid on various grounds, while others maintain its permissibility based on different sets of arguments.

Regardless of the above polemics, the majority of Muslim scholars seem to have reached a more balanced resolution by not regarding all types of insurance contracts as forbidden. To be specific, they argue that ta'mintijari, commercial insurance, is forbidden, while ta'minta 'awuni or tabaduli, mutual or co-operative insurance, is considered valid. This particular resolution has been reached at various forums, including the second conference of the Islamic Research Academy held in Cairo in 1965,(Al-Qarradaghi, 2008) the tenth meeting session of the Council of Senior Scholars of Saudi Arabia held in Riyadh in 1977, the first session of the Islamic Fiqh Academy under the 
auspices of the Organization of Islamic Conference (OIC) held in Mecca in 1398H/1978M, (Talal De Lorenzo, 2004) and the second meeting of the above Academy in 1406H/1985M.(AlQarradaghi, 2008)

The above resolutions seem to have received a positive response from Muslim countries as indicated by the establishment of Islamic insurance institutions, also known as takaful, all over the world. From the existence of only one Islamic insurance provider in 1979, there are currently 161 Islamic insurance companies operating in 32 different countries, (http://www.ey.com). Interestingly, almost all of these companies were established as joint-stock or public limited companies rather than purely mutual or co-operative entities as suggested by the resolution. Only Sudan can claim that its Islamic insurance companies operate under pure co-operative principles (Ahmad, 2006). This phenomenon seems to suggest that the original resolution may no longer be applicable to the modern takaful set-up. It is believed that the major disadvantage of mutual and co-operative organizations, i.e. that they can only obtain resources from their members and cannot raise equity capital, has strongly demotivated takaful providers from being established as mutual companies (Wilson, 2007). Hence, one big question arises as to whether this form of 'commercialization' is permissible from the Islamic point of view, particularly when the arrangement is subjected to the rules of prohibited gharar. This paper aims to examine this issue in the light of the Malaysian takaful industry practices.

\section{B. METODHOLOGY}

This paper sets out to examine the issues, which directly relate to this form of commercialisation. It argues that since the establishment of insurance companies based on commercial framework is impermissible, it could possibly affect the validity of present takaful arrangement. This study is mainly qualitative and relies greatly upon the documentation method.

\section{RESULT AND DISCUSSION}

\section{Islamic Insurance and it's Synonyms}

Before critically analysing the above issue, it is worth mentioning here that Islamic insurance is also known by several other terms, which include Co-Operative Insurance, Takaful as well as Halal Insurance. The use of these different terms easily be inferred from the names of the companies which we are known to offer Shari a compliant insurance products throughout the globe. The first term, i.e. Co-Operative Insurance.is mainly used by the companies in the Middle Eastern region, particularly Saudi Arabia and Sudan. For example, in Saudi Arabia, more than half of the companies incorporated therein we are named after the term 'Co-operative Insurance'. This is not surprising, because the law of the country requires any insurance company (registered in Saudi) to operate in accordance with the co-operative insurance method (Ahmad, 2006),(Wilson,2007).Moreover, co-operative insurance is basically considered as valid by the majority of the Muslim jurists, including the Saudi's Council of Senior Scholars. Nevertheless, as will be explained in the coming chapter, the operational dimensions of Islamic insurance may not necessarily be similar to co-operative insurance.

The term "'Halal Insurance"', on the other hand, was popularized by the first ever-independent Islamic insurance provider in the United Kingdom called Salaam Halal Insurance, (http://www.newhorizon-islamicbanking.com). The term, however, appears to be have faded away recently, as the company ceased to accept new business due to unfavourable market conditions. Takaful, is perhaps the most popular term in these days, since it is extensively used by the 
industry players as well as by the academia (Co-Operative Insurance). In Malaysia, a special act called the Takaful Act was introduced in 1984 to administer the operation of Islamic insurance companies in the country. Later in 2013, the Act was repealed and replaced by a more comprehensive Act called the Islamic Financial Services Act 2013 (IFSA), (http://www.bnm.gov.my). Consequently, takaful is statutorily synonymous with the notion of Islamic insurance in Malaysia. Many international events and published reports are also seen as proposing takaful as the proper term for the Islamic insurance industry in general. Some of the prestigious events regarding Islamic insurance are known as the International Takaful Summit (held annually in London) and The World Takaful Conference (held annually in Dubai). There are also many reports published by auditing firms and rating companies such as Standard \& Poor's, Ernst \& Young and AON that directly address Islamic insurance as takaful. One of the significant reports that highlight the overall performance of the Islamic insurance industry worldwide is The World Takaful Report, which is published by Ernst \& Young on an annual basis.

It should be noted, however, that not all parties seem to agree with the using of takaful to connote the whole idea of Islamic insurance. For example, in most Arab countries, particularly Saudi Arabia and Sudan, takaful appears to be specifically referred to the Islamic version of life insurance schemes, (Ahmad) (Ibrahim). The Islamic version of general insurance, on the other hand, is purposely distinguished by the using of the term Islamic insurance or co-operative insurance. In Swiss Re's serial publication called Sigma, it is also stated that Islamic insurance is distinguished from takaful. While the former refers to all concepts of Islamic insurance, the latter refers specifically to insurance models that use segregated funds for policyholders and share holders (Swiss Re, 2008). Unlike the Saudis and Sudanese cases, the scope of usage of the term takaful term in the latter case may well include Shari'a -compliant life and non-life insurance schemes. The main difference between takaful and Islamic insurance as suggested by Swiss Re seems to concentrate on the organizational structure of the insurance arrangement.

Despite the above differences, this paper will consider the notion of both Islamic insurance and takaful as interchangeable. This is perhaps consistent with the present international practices, as shown earlier. Moreover, since this research is restricted to the Malaysian market, in which the Takaful Act (and later IFSA 2013) has been enacted, the use of the term 'takaful' is perhaps more accurate. Hence, the term 'takaful' will be used interchangeably with Islamic insurance throughout the paper as if they were exactly identical.

\section{The Definition of Takaful}

Takaful is an Arabic noun derived from the root verb kafala, which means to guarantee,; secure,; ensure or be liable for(Ba'albaki, 2008). From this base, comes the derived stem takafala, which means to guarantee each other,; to vouch for each other, or to be jointly liable or responsible (Wehr, 1980). Takaful, which is the verbal noun of the latter, literally means mutual or joint responsibility, solidarity or mutual agreement (Wehr, Ba albaki). According to the Oxford Dictionary of English, takaful means a type of insurance system devised to comply with the Shari'a laws, in which money is pooled and invested (Allen, 1990). This rather technical definition tends to show that the term 'takāful' has already been acknowledged by the Western scholars to represent the idea of Islamic insurance.

Perhaps, one of the most established and authoritative technical definitions of takaful could be found in the Malaysian Takaful Act 1984. According to Section 2 of the Act, takaful is defined as follows: 
Takaful means a scheme based on brotherhood, solidarity and mutual assistance which provides for mutual financial aid and assistance to the participants in case of need whereby the participants mutually agree to contribute for that purpose.

As the first statutory definition of takaful, this definition seems to be very general and rather imprecise. Firstly, it appears as if the participants we are entitled to receive financial aid or compensation (from the Takaful Fund) in any situation of need, not necessarily subjected to the occurrence of certain risks or perils, as takaful is supposed to mean. Secondly, it tends to signify that takaful is a pure mutual undertaking in which no involvement from outside or a third party is expected. Nevertheless, the latter inconsistency is perhaps resolved by the subsequent definitions which clearly link takaful to a business arrangement (The Shari a. Furthermore). In fact, the Act is mainly enacted to provide for a procedure for the registration of takafulbusinesses, and to establish the conditions under which they operate, (Wilson).

A more conclusive and precise definition of takafulcanould perhaps be found in standards or guidelines produced by the two most authoritative bodies in the Islamic finance industry, namely the Accounting and Auditing Organization for Islamic Financial Institutions (AAOIFI) and the Islamic Financial Services Board (IFSB). AAOIFI in its Shari aStandards defines Islamic insurance, without mentioning the word takaful, as follows:

Islamic insurance is a process of agreement among a group of persons to handle the injuries resulting from specific risks to which all of them are vulnerable involves payment of contributions as donations and leads to the establishment of an insurance fund that enjoys the status of a legal entity. The resources of this fund are used to indemnify any participant who encounters injury. The fund is managed by either a selected group of policyholders, or a joint stock companies that manages the insurance operations and invests the assets of the fund, against a specific fee (AAOIFI, Shari a Standards).

Likewise, IFSB, in its published guidelines entitled 'Guiding Principles on Governance for Takaful (Islamic Insurance) Undertakings', describes takafulas follows:

Takaful is the Islamic counterpart of conventional insurance, and exists in both Family (and "Life") and General forms. Takaful is derived from an Arabic word that means joint guarantee. In a Takaful arrangement the participants contribute a sum of money as Tabarru' commitment into a common fund that will be used mutually to assist the members against a specified type of loss or damage. The underwriting in a Takaful is thus undertaken on a mutual basis, similar in some respects to conventional mutual insurance. A typical Takaful undertaking consists of two-tier structure that is a hybrid of a mutual and a commercial form of company - which is the Takaful operator (TO) - although in principle it could be a pure mutual structure (http://www.ifsb.org).

Based on the above definitions, it is clear that takaful is supposed to be built upon the principle of mutual help amongst the policyholders, or termed as participants. Each of them would voluntarily make a contribution to a common fund (known as the Participant's Risk Fund [PRF]) on the basis of tabarru', a donation, which will be later used to pay compensation to any of the participants who suffer losses or injuries from the insured events. This particular feature renders takaful comparable with the conventional mutual or co-operative insurance, whereby the participants are seen sharing and distributing the risks amongst themselves instead of transferring it them to the a third party. Through this co-operation, the participants are considered as to be both the insured and insurer at once. 
However, both mutual insurance and takafulare likely to differ in terms of the management of the fund. While the insurance fund in a mutual or co-operative entity is completely owned and managed by its own members, a takaful fund, on the other hand,canould possibly be managed by a joint-stock commercial entity (whilst its ownership maintains with the participants). Hence, based on this feature, takafulmay not necessarily be restricted to a purely mutual structure but could also involve a commercial setup, as the company who manages the fund (i.e. the takaful operator) is actively seeking profits by charging certain fees from the takaful fund. In reality, almost all takaful operators in these days are joint-stock or public limited companies instead of pure co-operative or mutual organizations (Ahmad).As a result, takafulcould be well described as a hybrid of a mutual and a commercial form of company. The mutual form of takafulcould be inferred from the relationship amongst the participants, while the relationship between the participants (or takaful fund) and the takafuloperator would constitute the commercial form of the arrangement. The latter relationship, especially which applies to the Malaysian takaful environment, will be further explored and critically examined in the forthcoming sections of this paper.

\section{The Commercialization of Takaful}

As previously stated, the majority of the takaful schemes available today are initiated and managed by joint-stock or public limited companies (which are obviously commercial in nature), rather than purely mutual organizations. Thus, it is perhaps right to suggest that takaful cannot be separated from the notion of 'commercialization'.

The word 'commercialization' comes from from the root word 'commerce', which refers to the activity of buying and selling, especially on a large scale. It originates from the middle of the $16^{\text {th }}$ century French or Latin word 'commercium', which means trade or trading (Allen, 1990).As an adjective, the word 'commercial' can mean relating to commerce (i.e. involving or relating to the buying and selling of goods) as well as done for profit (i.e. done with the primary aim of making money), (Rooney,Jellis, 2005). When a particular organization or activity is labelled as commercial (e.g. commercial bank or insurance) it is concerned with making money or profits rather than, for example, with scientific research or providing a public service (Collins, 2004).

Related to the above, the word 'commercialize', a verb, means to manage or exploit (an organization, activity, etc.) in a way designed to make a profit (The Concise Oxford Dictionary of Current English). If something is commercialized, it is used or changed in such a way that it makes money or profit, often in a way that people disapprove of (Collins Cobuild Advanced Learner's English Dictionary). It also means to apply business principles to something or run it as a business and to exploit something for financial gain (Bloomsbury Concise English Dictionary). Therefore, the word 'commercialization', which is a derivative (noun) of 'commercialize', can be defined as a process or state of managing, exploiting or altering something in a way that would make it very much synonymous with the notion of business, whereby the element of profit is undoubtedly sought after. This profit-seeking motive can sometimes have a negative connotion, as it tends to denote the enrichment of one party at the expense of another.

In this paper, takaful is considered to be greatly affected by the notion of commercialization, since most of the current takaful organizers, if not all, are business entities or corporations that see the opportunity of making money and profit out of providing/instigating management services to a rather socially-inspired undertaking. In the context of the Malaysian takaful industry, in particular, it appears that the mutual or co-operative-based organizational structure is almost irrelevant to the operators. In fact, it was identified earlier by the author that all the takaful schemes in Malaysia are initiated, marketed and organized by commercial organizations backed by the leading financial 
giants (which are obviously profit-seeking entities). Of all the 12 takaful companies currently operating, only one appears to be jointly owned by a co-operative body (Great Eastern Takaful Sdn. Bhd). Nevertheless, as will be explained next, this may not necessarily render the takaful arrangement similar to commercial insurance, which is considered forbidden by the majority of Muslim scholars. Yet its commercialization can still invoke certain issues which need to be carefully analyzed in order for the former to be completely dissociated from the latter. For instance, some possible ghararincidences can be detected in the operation of certain operators that might render the commercial side of takaful invalid (Noordin, 2012).

\section{Commercial Takaful vis-à-vis Commercial Insurance}

At first sight, takaful providers may seem to be similar to commercial insurers due to the fact that they are mostly, if not all, joint-stock companies or corporations which aim to make money or profit from the services rendered. Nevertheless, upon deeper investigation the notion of 'commercial' may prove to be different in both entities, and thus would lead to different legal rulings. It appears that the notion of 'commercial', which is synonymous with a profit-seeking motive, has led to the banning of conventional insurance but not takaful in general. Perhaps this distinction can be best explained by the fact that Shari alaw views a profit-seeking motive as legitimate so long as it conforms to the rules, ethics and norms of a business. This includes the avoidance of dealing with riba, gharar, maysir and other forms of unfair practice.

As maintain by many scholars, the operation of a commercial insurer is very much affected by the above elements, particularly gharar, and thus has led to its prohibition. On the other hand, the revenue and profit for a commercial takaful operator should only be sought through legitimate or Shari a-compliant means, which are supposed to be free from those prohibited elements. In Malaysia, and perhaps worldwide, this is mainly done through the application of several nominate contracts such as wakala bi ajr, remunerated agency, mudaraba, profit sharing, and ji ala, reward. As will be explained in detail later on, these contracts appear to allow the operators to legally secure their revenue and profit consistent with their role as a hired agent, entrepreneur or worker respectively.

Yet these contracts, which are obviously not in the tabarru ' category, are still subjected to the rules of gharar and thus can possibly be judged as invalid (due to gharar) if their conditions are not fully met. Moreover, in most cases, the takaful operators are also seen as taking advantage of combining two or more of these contracts in order to obtain higher revenue and profit. In addition, the drive to secure higher profits can sometimes inspire the takaful operator to engage in rather controversial practices. These may include the modification of the contract's original specifications (such as the altered definition of profit in the mudaraba contract) and the application of the contract in a disputed area (such as applying the ji ala contract to justify the sharing of an underwriting surplus).

Regardless of these controversies, the correct application of these contracts is considered to be the main reason for the validity of commercial takaful as opposed to commercial insurance. Perhaps the application of these contracts has made certain specifications of the commercial notion in takaful substantially different from that found in commercial insurance. The explanations of why the notion of 'commercial' in takaful is different from commercial insurance due to the application of the above-mentioned contracts follow in the next sections. 


\section{Responsibility to Indemnify}

In commercial insurance, the concept of risk transfer is applied whereby the insurance company is seen as taking full responsibility to indemnify the insured (during the occurrence of an insured peril) in exchange for premiums received from the latter. This transaction is obviously mu'awada, financial exchange, in which the insurer aims to make a profit out of the insurance operation (AAOIFI, Shari aStandards, 2007). In other words, the whole insurance arrangement is initiated and endorsed by the company's own name under the notion of a pure sale contract. Conversely, the concept of risk sharing amongst the participants (instead of risk transfer) is applied in takaful whereby the operator only assumes the role as an agent, worker or entrepreneur to the takaful arrangement, but not as an insurer (Al-Qarradaghi).It is the group of participants that is actually considered to be the insurer (as well as the insured) in this arrangement, similar to mutual or cooperative types of insurance, based on the principles of tabarru' and ta 'awun (AAIOFI, Shari a Standards). In short, the commercial aspect of the takaful operator in this regard is limited to the aspect of providing management services to the insurance undertaking, which in principal is initiated by the participants. Even though this can also be considered as mu'awada, it is obviously underlain by several contracts other than sale, i.e. wakala bi ajr, mudaraba or ji ala.

\section{Accounts Management}

Following the above feature, the takaful operator is required to maintain two separate accounts, one for the shareholders' rights and liabilities and the other for the rights and liabilities of the participants or policyholders (Ibid). To be specific, all contributions paid by the participants are credited into the latter account, which is commonly known as the Participant's Risk Fund (PRF), to cover all the expenses related to the provision of the insurance services. Any residual amount recorded by the account (after deduction of expenses and indemnity amounts) is considered as surplus and remains the property of the participants collectively (AAOIFI, Shari a Standards). The company, or to be specific, the shareholders, has no rights to whatever amount that is credited to or remains in this account apart from their stipulated proportion of wakala charges, and in some cases may also include performance fees. On the other hand, there is no need for the commercial insurer to hold two different accounts, since all premiums collected are immediately owned by the company in exchange for its insurance protection (Al-Qarradaghi)(AAOIFI, Shari a Standards). Obviously, this is parallel to the characterization of insurance as a contract of sale, whereby the premium (paid by the policyholder) is considered to be the price, while the financial protection (offered by the insurer) is regarded as the object of sale. Consequently, any remaining premiums (after deducting claims and other operating expenses) also belong to the latter.

\section{The Sources of Profit}

As a result of the previous two characteristics, the definition and recognition of profit for both takaful and insurance companies should also be different from one another. Perhaps this could be the ultimate test for a commercial takaful operator, since the over-emphasis on maximization of profit could possibly lead it beyond the limit of a legitimate commercial entity due to its tendency to engaging in prohibited elements such as gharar, jahalaand so on. The revenue and profit for commercial insurers are mostly sourced from the premiums paid by the policyholders, since they constitute part of the former's assets (AAOIFI, Shari a Standards). The more premiums it collects and the less compensation it pays, the bigger profit it will make (Al-Qarradaghi). Technically, an underwriting surplus, which is generally defined as the difference between the premiums collected and the subsequent outflow (i.e. claims, reserves, operational expenses, etc.), is recognized as profit attributable to the shareholders in commercial insurance (Ibid). Apart from this primary 
source, an insurer will also gain revenue and profit from investing its own capital as well as the above premiums in various fields including those associated with riba, gharar, maysir and other prohibited elements.

This is not the case for a commercial takaful operator, since it does not automatically own all the contributions paid by the participants as well as the surplus recorded in the latter's account. Due to its role as a mere trustee, any remaining amount in the PRF is not regarded as the shareholders' profit. Instead, it remains the property of the policyholders as a group, and could partly or wholly be distributed between them under the notion of surplus-sharing(AAOIFI, Shari a Standards)(AlQarradaghi). Notwithstanding that, a commercial takafuloperator can still acquire revenue and profit from the participants' contributions consistent with its role as an agent or manager of the pooled fund. This can be in the form of fees and charges imposed on contributions and the PRF or through a share in the profit or surplus of the Fund, which corresponds to the application of several specific contracts that underlie the relationship between the participants (or PRF) and the operator. In the latest guidelines issued by BNM, which takes effect on 1st October 2011, the following requirements need to be observed by takaful operators in determining the appropriate amount of the above incomes (http://www.bnm.gov.my):

a. There must be a specific and clear intended outcome from the work undertaken to justify the remuneration. There shall not be double charging within a takaful product;

b. The remuneration to be taken shall be appropriate and reasonable, and determined with due regard to provide fair treatment to stakeholders;

c. Implications on takaful funds, in particular on the fund's long-term viability, shall be considered; and

d. The level of of remuneration to be taken must be commensurate with the complexity of the services rendered and the associated risks.

Below is a summary of possible income for takaful companies, particularly in Malaysia, that may constitute profits for the shareholders.

\section{Fixed Wakala Fees and Charges}

As an agent who manages the whole takaful operation, the company is entitled to charge fees from the participants' contributions based on the contract of wakalabiajr, remunerated agency. In most cases, a fixed general wakala fee is charged upfront in the form of an agreed percentage, up to 40 per cent of the participants' contribution. According to Wan Deraman and Ismail, this upper limit is regulated by the Central Bank of Malaysia (BNM), though the specific guidelines pertaining to this rule could not be found by the author. In contrast to this general fee, some companies, such as Prudential BSN Takaful Berhad (PBTB), may charge a more specific wakala fee from the participants' contributions such as a service wakala charge and a risk management wakala charge to differentiate between two main types of agency tasks (PBTB, Certificate Document). Another company, MAA Takaful Berhad (MATB), seems to charge a wakalatharawat fee for investing the takaful fund. Basically, the rates of these upfront charges is determined by two main factors: (1) the level of management expenses expected to be incurred by the shareholders's fund in servicing the takaful certificates throughout the contract term; and (2) an appropriate provision of margin to compensate shareholders for the effort taken in managing takaful operations (BNM).

From these charges, the shareholders's account may be supplied with profit (at the end of a particular financial year) if the operational expenses are lower than the overall wakala fees received. In practice, however, the wakala fees are argued to be only sufficient to cater for 
distribution (agent's commission) and management expenses (Kassim, 2007). Yet by referring to the operators' income statement, it is obvious that the fees are normally insufficient to cover both expenses, even for companies that have recorded huge profits such as Etiqa Takaful Berhad (ETB), (Noordin). In most cases, however, this deficiency leads to a net loss for the companies for that particular financial year. This is especially true for newly established companies such as Sun Life Malaysia Takaful Berhad ([SLTB] formerly known as Commerce Aviva Takaful Berhad - during 2008-2009), PBTB (during 2007-2008) and Hong Leong MSIG Takaful (HLMT-almost every year).

\section{Share of Direct Investment Profits (as an Entrepreneur)}

In general, it is assumed that every takaful operator will venture into a mudaraba contract with the participants, especially when the latter's fund is to be invested by the former (AAOIFI, Shari'a Standards) (Al-Qarradaghi). In practice, however, the application of this contract is perhaps inevitable in almost every Family Takaful product, since savings are obviously considered an integral part, but may not necessarily be applicable to General Takaful schemes. This is due to the short-term nature of the latter schemes and the absence of a particular savings account (i.e. PIF) for the participants. Yet the application of mudarabato general products is deemed relevant by some operators in Malaysia such as Syarikat Takaful Malaysia Berhad (STMB) and PBTB, whereby the PRF is invested according to the contract mentioned above. Although this practice appears to be consistent with the AAOIFI's general guidelines (Shari a Standard), it is suggested that the standard is meant specifically for Family Takaful lines where the PIF is present. The new guidelines issued by the Central Bank appear to concur with this suggestion (BNM). Moreover, the fact that most operators do not engage in this kind of practice (i.e. investing the PRF via a mudaraba contract) tends to support the above statement.

According to this contract, the amount accumulated in the takaful fund (either the PRF or PIF) is invested by the operator as mudarib, entrepreneur, in various Shari a-compliant investments. Any profit generated therefrom over and above the original amount of capital is shared according to a pre-agreed ratio. In practice, the profit sharing ratio varies across operators as well as products and can range from 40:60 to 80:20 to the participants and operators respectively, (STMB) (PBTB). Accordingly, the higher the profit generated from the investment, the larger the amount attributable to the shareholders. However, if the investment is unsuccessful, the operators will not receive anything. In addition, the operators can be held liable for the loss if they are found to be guilty of misconduct or mismanagement. It should be mentioned however, that the definition of mudaraba profit as given above has been altered to a certain extent by one particular takaful operator, i.e. STMB, who claim to apply a modified mudarabamodel. Instead of sharing direct investment profit, the company shares the underwriting surplus under the name of mudaraba profit. This practice is controversial andwill be dealt in other research paper. In a nutshell, it could be suggested that the application of mudaraba has marked the commercial feature of takaful, since an element of profitseeking is without a doubt present.

\section{Performance-Related Charges}

Apart from the above two sources of revenue, takaful operators may also charge various types of fee contingent upon the achievement of certain desired qualities or output in regard to the management of the takaful undertaking. This performance-related income is obviously variable in nature, as opposed to the fixed wakala charges mentioned earlier. The takafuloperators who employ this practice, particularly Takaful IkhlasSendirianBerhad (TISB), HSBC Amanah Takaful SendirianBerhad (HATSB), ETB, SLTB and MATB suggest that it is consistent with the contract of 
ji ala, reward for achieving certain desired objectives. Notwithstanding that, there seems to be no specific reference made to the above contract as far as the written policy documents and guidelines for these operators are concerned. Basically, the contract of ji ala ties the reward payment (for the operator) to the actual output and performance of the takaful operations. If the output or performance is short of what is prescribed, the reward will not be due and payable. This sort of income is argued to be crucial in securing profits for the companies' shareholders, since the previous two sources are hardly sufficient to cover all the incurred expenses. For example, in the case of ETB, one the most profitable operators in Malaysia, this type of revenue contributed between 42 to 89 per cent of the total gross profit (before zakat and taxation) recorded by the company between 2007 and 2010 (http://www.etiqa.com.my).

There are at least two areas or tasks where the contract is said to be relevant/applicable by the respective takaful operators in Malaysia, namely: (1) in investing the participants' fund (either PRF or PIF) so that a desired level of profit is achieved; and (2) in managing the PRF prudently so that an underwriting surplus is attained.

The first task is probably similar to the application of mudaraba, as explained earlier. The only difference is that the operator is acting as an investment agent instead of an entrepreneur and will charge a certain percentage (e.g. 10 per cent) of the profit realized as a reward, or to be specific, as an investment performance fee. Obviously, the end result of both contracts, particularly the share of investment profit attributable to the shareholders, would be relatively the same. Few operators declare the above charge in investing the PRF, including TISB and CATB. However, by referring to their financial reports, it seems that the above performance-related fees have yet to be implemented by both companies. Conversely, HLMT, despite being silent regarding the above fee, actually charges between 9 to 12 per cent of the PRF investment profit (http://www.hlmsigtakaful.com.my).

The application of $j i$ 'ala on the second task appears to be more significant, as it tends to justify the sharing of an underwriting surplus from the PRF (by the operator), which is deemed by many to be inappropriate. This is due to the nature of an underwriting surplus, which is commonly viewed as the exclusive property of the policyholders. Since an underwriting surplus is actually derived from the remains of the participants' contributions (after deducting claims and other related expenses), it is argued to technically and legally belongs to the participants as a group (Ayub, 2008), (Arbouna, 2008). Nevertheless, the sharing of PRF surplus by the operator is legally recognized by BNM under the notion of 'performance fees', provided that certain requirements are observed (BNM). Some companies, such as TISB, prefer to call this sort of charge a 'surplus administration charge'. In practice, the operators are seen as applying different surplus sharing ratios which range between $80: 20$ and 20:80 to the operator and participants respectively. Amongst the operators which have been identified to implement this practice are ETB, TISB, CATB, MATB and HATSB. Due to the controversial nature of this practice, it will be extensively studied in other research paper.

In conclusion, it can be suggested that the categorization of takaful as a commercial entity is only limited to the extent of initiating a business organization (which is profit-oriented) to manage and organize insurance schemes which in fact are mutually undertaken by the policyholders under the principle of tabarru' and ta 'awun. This is different from commercial insurance in which all insurance activities are undertaken and treated by the insurance company as a pure business endeavour, thus do not necessitate the initial mutual arrangement amongst the insured. 
Perhaps the commercialization of takaful is unavoidable these days, since it is required by the law of most countries, including Malaysia that the takaful operator must be registered and hold a valid licence prior to the commencement of its operation. In general, the licence will only be granted to any organization which fulfils certain requirements, which amongst others include the acquisition of vital skills or experience and a considerable amount of capital to set off the schemes. As a result, one can expect to see most of the licences given to business corporations or public limited companies instead of groups of participants or co-operative bodies. Nevertheless, it is anticipated that the notion of commercialization will gradually lessen in the future, as more co-operative movements will be ready to organize such an undertaking. Until then, it is perhaps right to say that current takaful operators are in fact commercial entities, but (theoretically) within the permitted boundaries and do not have the same characteristics as the forbidden type of commercial insurance.

\section{CONCLUSION}

The categorization of modern takafulcompanies as commercial entities is mainly due to the fact that they are mostly structured as joint-stock or public limited companies, which basically are profit-seeking entities. Nevertheless, this will not necessarily render the takaful arrangement similar to conventional insurance, which is forbidden due to its commercial characteristics. One of the key reasons for the above divergence is that the former only acts as a remunerated agent who undertakes to manage and organize all the insurance-related matters on behalf of the policyholders. It is the participants who are actually willing to provide insurance protection amongst themselves under the notion of tabarru' and ta awun. This is not the case in conventional commercial insurance whereby the insurer takes full responsibility to indemnify the insured in exchange for the premium received in parallel to the contract of sale.

The validity of this commercial type of takaful arrangement is perhaps very much dependent upon the specific and correct roles that the operator plays consistent with the application of several specific nominate contracts. In the Malaysian takafulenvironment there appears to be three main contracts widely applied by the takafuloperators, either in its solitary form or as a combination of two or more contracts, in order to underlie the above relationship as well as to gain profit. These contracts include wakala bi ajr (remunerated agency), mudaraba (profit-sharing), and ji ala (reward). It is suggested, however, that only if these contracts are correctly and appropriately applied will the subsequent acquired revenue and profits be valid for the commercial takaful operator. Otherwise they could possibly be deemed invalid due to their association with gharar, jahala and other unfair practices. 


\section{References}

AAOIFI. (2007). Shari a Standards for Islamic Financial Institutions 1429H-2008.Bahrain: AAOIFI. (2008). Shari a Standards for Islamic Financial Institutions 1429H-2008.Bahrain: AAOIFI.

Ali Muhyi al-Din al-Qarradaghi. (2005).Al-Ta'min al-IslamiyyDirasaFiqhiyyaTa'siliyyaMuqarana bi al-Ta'min al-TijariyyMa'a al-Tatbiqat al-'Amaliyya. Beirut : Dar al-Basha'ir al-Islamiyya.

Ahmad, Asem Samih. (2006). A Critical Study of Takaful (Islamic Insurance) and Its Modern Implementation' (PhD Thesis, University of Birmingha).

Ayub, Muhammad. (2008).Understanding Islamic Finance.England :John Wiley and Sons Ltd.,

Bloomsbury Concise English Dictionary.

BNM, 'Guidelines on Takaful Operational Framework', p. (15 May

2011).http://www.bnm.gov.my/guidelines/06_others/Concept\%20Paper\%20\%20Guidelines\% 20on\%20Takaful\%200perational\%20Framework.pdf.

Collins Cobuild Advanced Learner's English Dictionary.

Collins Cobuild Advanced Learner's English Dictionary, HarperCollins Publishers, 2004.

Engku Rabiah Adawiah Engku Ali and Hassan Scott P. Odierno. (2008). Essential Guide to Takaful (Islamic Insurance). Kuala Lumpur : CERT Publications Sdn. Bhd.

Ernst and Young. (12 July 2011). The World Takaful Report 2011: Transforming Operating Performance

http://www.ey.com/Publication/vwLUAssets/World_Takaful_report_April_2011/\$FILE/WTR20

11EYFINAL.pdf.

Etiqa. (18 June 2011).'Director's Report and Audited Financial Statements', , 30 June 2008. http://www.etiqa.com.my/English/AboutUs/Financials/Documents/fs_2008/fin_stat_etb08_eng .pdf.

(18 June 2011). 'Director's Report and Audited Financial Statements', 30 June 2010.http://www.etiqa.com.my/English/AboutUs/Financials/Documents/fs_2010/Etiqa\%20Tak aful\%20Berhad\%20-\%20June\%202010\%20(Eng).pdf.

Financial Statements. (23 June 2011).

http://www.hlmsigtakaful.com.my/images/HLTMTFinancialStatementsFY0708.pdf, p.55.

Horizon. (12 July 2011).Salaam Halal Insurance Fails to Attract Interest, January 2010. http://www.newhorizon-islamicbanking.com/index.cfm?action=view\&id=10922\&section=news

Ibid., Hans Wehr, in J. Milton Cowan, ed. (1980). A Dictionary of Modern Written Arabic. [3rded]. Beirut: Librairie Du Liban. 
IFSB. (7 July 2011).Guiding Principles on Governance for Takaful (Islamic Insurance) Undertakings, December 2009.

http://www.ifsb.org/standard/ED8Takaful\%20Governance\%20Standard.pdf.

Islamic Financial Services Act 2013. (1 October 2013).

http://www.bnm.gov.my/documents/act/en_ifsa.pdf.

Kathy Rooney and Susan Jellis, Eds. (2005).Bloomsbury Concise English Dictionary [2 ${ }^{\text {nded.]. }}$ London: A \& C Black Publishers Limited.

Mohammed, Burhan Arbouna. (2008).Regulation of Takaful Business : A Shari ah Overview of Contractual Aspects of Takaful Models, in Essential Readings in Islamic Finance, ed. by MohdDaudBakar and EngkuRabiahAdawiahEngkuAlwi.Kuala Lumpur : CERT Publications Sdn. Bhd.

R.E. Allen, ed. (1990). The Concise Oxford Dictionary of Current English. [8 ${ }^{\text {thed] }}$. Oxford :OxfordUniversity Press.

Rodney Wilson. (2007). Concerns and Misconseptions in the Provision of Takaful, in SohailJaffer (ed.) Islamic Insurance: Trends, Opportunities, and the Future of Takaful. United Kingdom: Euromoney Institutional Investor Plc.

RuhiBa`albaki and Munir Ba’albaki. (2008). Al-MawridMuzdawaj.Beirut : Dar al-'Ilm li al-Malayin.

The Concise Oxford Dictionary of Current English

Yusuf, Talal De Lorenzo, ed. (2004). Compendium of Legal Opinions on the Operations of Islamic Banks, vol. iii Wakala, Kafala, Rahn and Takaful. London: Institute of Islamic Banking and Insurance.

Zainal Abidin Mohd. Kassim. (2007). 'Takaful: A Question of Surplus', in Islamic Insurance Trends, Opportunities and the Future of Takaful, ed. by Sohail Jaffer. London: Euromoney Institutional Investor PIc. 